IN addition to the spectrum of biological action already known to be exhibited by acetylsalicylic acid (ASA) as an analgesic, anti-inflammatory and platelet aggregation inhibitor, there is growing evidence of a stimulatory effect on the immune system. ASA has been found to increase the production of cytokines and to increase the activity of various leukocytes. The action of ASA on the activity of mouse peritoneal macrophages was therefore investigated in the present study. Therapeutically effective concentrations of ASA, which are known to decrease levels of prostaglandins, had neither a stimulating nor an inhibiting influence on antibody-dependent cellular cytotoxicity (ADCC) or on the binding capacity of macrophages with regard to SW 948 tumour cells. Likewise ASA had little or no adverse effect on the capacity of the macrophages for stimulation by interferon-gamma (IFN-gamma) and interleukin-4 (II-4). Taken together, the immunostimulant effect of ASA shown in the literature as an increased production of interleukin-2 (IL-2) and IFN, could not be confirmed on the basis of the macrophage cytotoxicity.

\section{Role of acetylsalicylic acid in cytokine stimulation of macrophages in antibody- dependent cellular cytotoxicity (ADCC)}

\author{
M. Jäpel, ${ }^{1}$ H. Lötzerich ${ }^{1, C A}$ and K. Rogalla ${ }^{2}$
}

'Institute for Experimental Morphology, German Sports University, P.O. Box 4503 27, 50927 Köln, Germany; '2Drug Research Center, Bayer AG, Aprather Weg, 5600 Wuppertal 1, Germany

CA Corresponding Author

Key words: Acetylsalicylic acid, ADCC, Biological response modifiers, Macrophages

\section{Introduction}

Many lines of experimental evidence suggest that acetylsalicylic acid (ASA) is able to act as an immunomodulating agent. ASA increases the production of interleukin-2 (IL-2) and interferon (IFN) ${ }^{1-7}$ On oral administration of ASA, synthesis of IL-2 by peripheral mononuclear blood cells reaches its peak after $10 \mathrm{~h}$ and the synthesis of IFN-gamma is greatest after $24 \mathrm{~h}$. On stimulation with ASA in vitro the peaks of IL-2 and IFN-gamma synthesis occur somewhat later, i.e. after $24 \mathrm{~h}$ and $72 \mathrm{~h}$ respectively. Moreover, cytokine synthesis is dependent upon the presence of monocytes, as no effect was observable in isolated lymphocytes cultures. ${ }^{4,7}$ The time of occurrence of the IL-2 and IFN-gamma maxima thus corresponds to the model of cytokine regulation ${ }^{2}$ and underlines the importance of the monocytes and macrophages in this activation of the immune system. This provides further evidence of the scientific basis of the immunological effect of ASA, which can be explained in terms of inhibition of prostaglandin synthesis by monocytes and macrophages. ${ }^{1,2,4,8,9}$ In this reaction ASA inhibits cyclooxygenase activity irreversibly by covalent binding of its acetyl group to the enzyme. ${ }^{10}$ Among the arachidonic acid metabolites the prostaglandins of group E (PGE) exert a suppressive effect on the immune system. ${ }^{11}$ The proliferation of T-lymphocytes, lymphokine production, and the cytotoxicity of $\mathrm{Nk}$ cells, lymphocytes and macrophages are inhibited by PGE, ${ }^{12-18}$ while tumour growth $^{15,19.20}$ and metastatic growth ${ }^{21-23}$ are promoted. The depression of the immune system can therefore be explained on the basis of elevated PGE production or by increased sensitivity to PGE. Conversely, PGE-synthesis inhibitors act as immunostimulants. PGE-synthesis blockers reduce or slow down tumour growth. ${ }^{19,24-26}$ ASA also enhances the cytotoxicity of Nk cells in tumour-bearing animals. ${ }^{27}$ There is also an epidemiological study according to which ASA exerts a protective effect against cancer of the colon; regular intake of ASA was found to reduce the risk of colon cancer significantly both in men and in women. ${ }^{28}$ Since the activation of macrophages plays an important part in tumour defence, ${ }^{29-31}$ and the macrophages are directly affected by the inhibition of PGE synthesis, the aim of the present study was to determine the extent to which ASA influences the activation of macrophages by IL- 4 and IFN-gamma.

\section{Materials and Methods}

Mice: Female, syngenic C57Bl/6 mice, 8-12 weeks of age, were purchased from IFFA Credo (SaintGermain-Sur-L'Arbesle, France) and were matched for age in each experiment. The animals were housed conventionally in plastic cages and were given water and food ad libitum. 
Cell line: The SW 948 colonic adenocarcinoma cell line was established by Leibovitz et al. ${ }^{32}$ and was kindly provided by H. Löhrke (German Cancer Center (DKFZ), Heidelberg, Germany). The cell line was maintained in Leibovitz's L-15 medium containing $10 \%$ foetal bovine serum, $2 \mathrm{mM}$ glutamine, $100 \mathrm{U} / \mathrm{ml}$ penicillin/streptomycin and $2.5 \mu \mathrm{g} / \mathrm{ml}$ fungizone (all ICN-Flow, Germany). The tumour cells were cultured in $75 \mathrm{~cm}^{2}$ plastic tissue flasks and passed weekly.

Cytokines: Interleukin- $4\left(3 \times 10^{4} \mathrm{U} / \mathrm{ml}\right)$ was supplied by Genzyme (Germany). Recombinant IFN-gamma $\left(1 \times 10^{5} \mathrm{U} / \mathrm{ml}\right)$ was purchased from Boehringer (Germany). Both cytokines were diluted in PBS supplement with $0.1 \%$ bovine serum albumin, aliquotted and stored at $-80^{\circ} \mathrm{C}$ until used.

Polyclonal antibodies: Anti-SW 948 serum was prepared in C57BL/6 mice as follows, according to the method of Johnson et al. ${ }^{33}$ in a first step mice received an i.p. injection of $10^{6}$ tumour cells in $0.1 \mathrm{ml}$ Hank's buffered salt solution (HBSS). Two weeks later, in a second step, the mice received an i.p. injection of $10^{6}$ tumour cells in HBSS. Ten days after the final injection 2-3 $\mathrm{ml}$ blood was collected by cardiac puncture. Serum was separated after centrifugation and $50 \mu \mathrm{l}$ aliquots were stored at $-80^{\circ} \mathrm{C}$ until use. The antisera alone were not capable of causing tumour cell lysis.

Acetylsalicylic acid: The acetylsalicylic acid was purchased from Bayer (Germany) in the form of the lysine salt $\left(\right.$ Aspisol $\left.^{\mathrm{R}}\right)$. It was dissolved under sterile conditions in distilled water for injections. It is very important to prepare the solution of Aspisol immediately before use, because hydrolysis of acetylsalicylic acid sets in very quickly in aqueous solutions.

Harvest of peritoneal macrophages: Mice were killed by cervical dislocation and proteose peptone- and thioglycollate-elicited macrophages were harvested $72 \mathrm{~h}$ after injection of $0.6 \mathrm{ml}$ of each agent by peritoneal lavage. Eight $\mathrm{ml}$ of cold HBSS containing $10 \mathrm{U} / \mathrm{ml}$ heparin was injected into the peritoneal cavity of the mice and peritoneal exudate cells were harvested. The cell suspensions were centrifuged at $500 \times \boldsymbol{g}$ for $5 \mathrm{~min}$. The cells were resuspended in minimal essential medium (MEM; Gibco, Germany) supplemented as above and a small sample was taken for total and differential cell counts. The thioglycollate treatment leads to an over 95\% macrophage content of the peritoneal exudate cells, in contrast to peptone-elicited macrophages (65\%). The peritoneal exudate cells were added to 96-well flat-bottom plates (Bibby, UK) at the desired macrophage concentrations and were incubated at $37^{\circ} \mathrm{C}$ in a humidified atmosphere of $5 \% \mathrm{CO}_{2}$. After $1 \mathrm{~h}$ of incubation the nonadherent cells were washed off, obtaining a monolayer with more than $98 \%$ macrophages. ${ }^{34}$ The macrophages were now ready for use in the antibody-dependent cellular cytotoxicity (ADCC) or binding assays. In experiments with IFN all macrophages were cultured for the duration of $48 \mathrm{~h}$. Two hours of stimulation with IFN or ASA indicates the period before starting the ADCC or binding assays. In costimulation with IL-4 all macrophages were cultured and stimulated over a $24 \mathrm{~h}$ period before starting the assays.

ADCC: The slow form of ADCC was estimated as previously described. ${ }^{35}$ In brief, $4 \times 10^{4}$ SW 948 tumour cells labelled with $\left[{ }^{3} \mathrm{H}\right]$ thymidine (TRK. 120 , sp. act. $25 \mu \mathrm{Ci} / \mathrm{mmol}$, Amersham Buchler, Braunschweig, Germany) were added to the monolayers of macrophages $\left(1 \times 10^{5}\right.$ per well $)$ in the 96-well flat-bottom plates either with or without the polyclonal anti-SW cell antiserum (Ab). The plates were harvested after an incubation period of $48 \mathrm{~h}$ at $37^{\circ} \mathrm{C}$ in a humidified atmosphere of $5 \% \mathrm{CO}_{2}$. A cellfree supernatant $(100 \mu \mathrm{l})$ was removed and added to scintillation cocktail (Canberra Packard, Frankfurt, Germany). The ADCC was quantified using the relationship:

$\%$ Lysis $=\frac{-(\mathrm{cpm} \text { released in tests without } \mathrm{Ab}-\text { spont. rel. })}{\mathrm{cpm} \text { total releaseable }(=\text { maximum release })} \times 100$

All tests were carried out in triplicate and repeated three times.

Binding assay: The estimation of the binding capacity of macrophages to tumour cells was performed as previously described in detail. ${ }^{36}$ In brief, $4 \times 10^{4} \mathrm{SW}$ 948 tumour cells labelled with $\left[{ }^{3} \mathrm{H}\right]$ thymidine (TRK.120, sp. act. $25 \mu \mathrm{Ci} / \mathrm{mmol}$, Amersham Buchler, Braunschweig, Germany) were added to the monolayers of macrophages $\left(1 \times 10^{5}\right.$ per well $)$ in the 96-well flat-bottom plates either in the presence or in the absence of the polyclonal anti-SW cell antiserum (Ab). After centrifugation at $50 \times \boldsymbol{g}$ for $1 \mathrm{~min}$ and an incubation time of $15 \mathrm{~min}$ unbound tumour cells were completely removed by aspiration and four vigorous washings with HBSS. The remaining bound target cells were lysed by adding $200 \mu \mathrm{l}$ of $0.25 \%$ sodium dodecyl sulphate (Sigma, Germany) to each well. Binding was quantified using the relationship:

No. of bound target $=\frac{\mathrm{cpm} \text { bound to macrophages }}{\text { total } \mathrm{cpm} \text { added }} \times 4 \times 10^{4}$

All tests were carried out fourfold and repeated three times. 
Statistics: Experimental results were analysed for significant differences between points at confidence level $p<0.05$ by analysis of variance.

\section{Results}

The ASA concentrations studied $(75 \mu \mathrm{g} / \mathrm{ml}$ and $100 \mu \mathrm{g} / \mathrm{ml}$ ) did not have any inhibiting or stimulating effect on the cytotoxic activity of the peptone-elicited macrophages (Figs 1 and 2). This is clear both from the antibody-independent and from the antibodydependent cytotoxic capacity of the macrophages with respect to the tumour cells. Accordingly, the ADCC value was also unchanged. By contrast, IL-4 concentrations of 10 and $20 \mathrm{U} / \mathrm{ml}$ were found to activate the peptone-elicited macrophages to the level of the thioglycollate macrophages. Similarly, costimulation of the macrophages with IL- 4 and ASA induced a significant increase in macrophage activity. A weak inhibition of macrophage activity was observable after costimulation in comparison with stimulation exclusively with IL-4, though this was not significant (Figs 1 and 2).

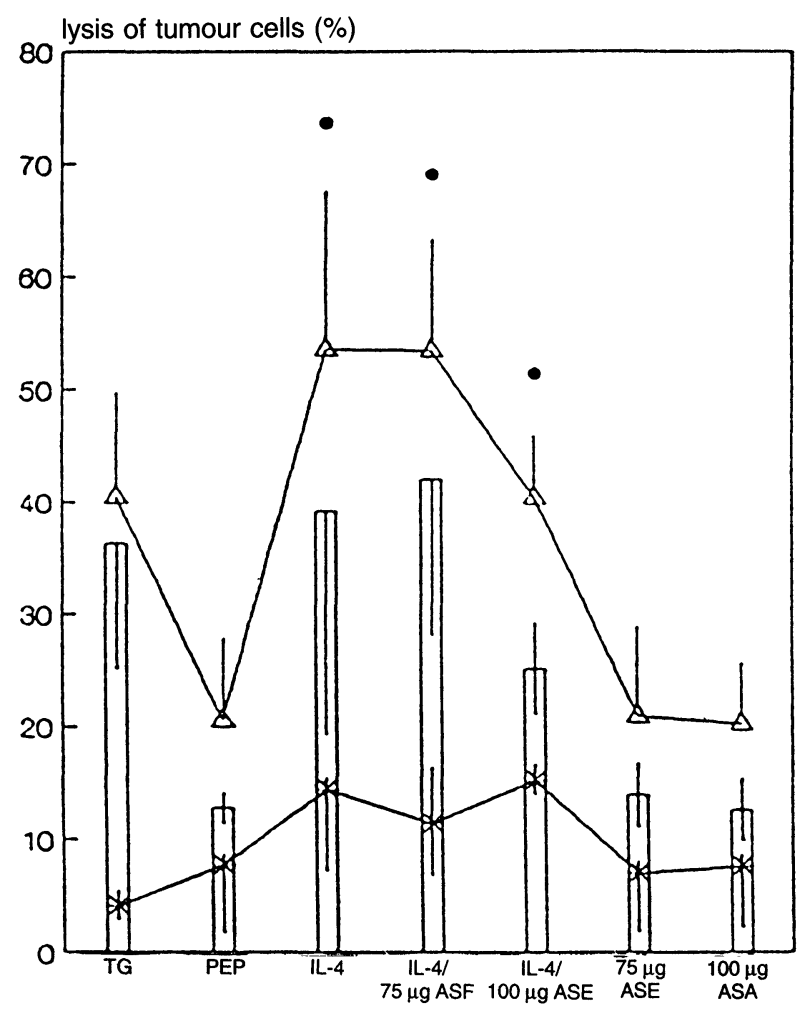

FIG. 1. Results of ASA costimulation with IL-4 in tumour cell lysis. Peritoneal macrophages (MP) from mice injected with proteose peptone (PEP) were prepared at $1 \times 10^{5} \mathrm{MP} /$ well. After nonadherent cells were removed, $200 \mu \mathrm{l} \mathrm{MEM}{ }^{+}$with either 75 or $100 \mu \mathrm{g} \mathrm{ASA} / \mathrm{ml}$ with or without $10 \mathrm{U}$ $\mathrm{IL}-4 / \mathrm{ml}$ were added. After $24 \mathrm{~h}$ the total volume was replaced by $200 \mu \mathrm{l}$ fresh medium with $4 \times 10^{4}\left[{ }^{3} \mathrm{H}\right]$ thymidine-labelled SW 948 cells, and with or without antibodies $(A b)$. After $48 \mathrm{~h}, 100 \mu \mathrm{l}$ supernatant was aspired from each sample and cpm were determined. The cell lysis with $A b(\triangle)$, the cell lysis without $A b(*)$, and the ADCC (bars) were calculated as described in the text. Thioglycollate (TG) elicited MPs served as control, only. (•) Significantly different to PEP-control.

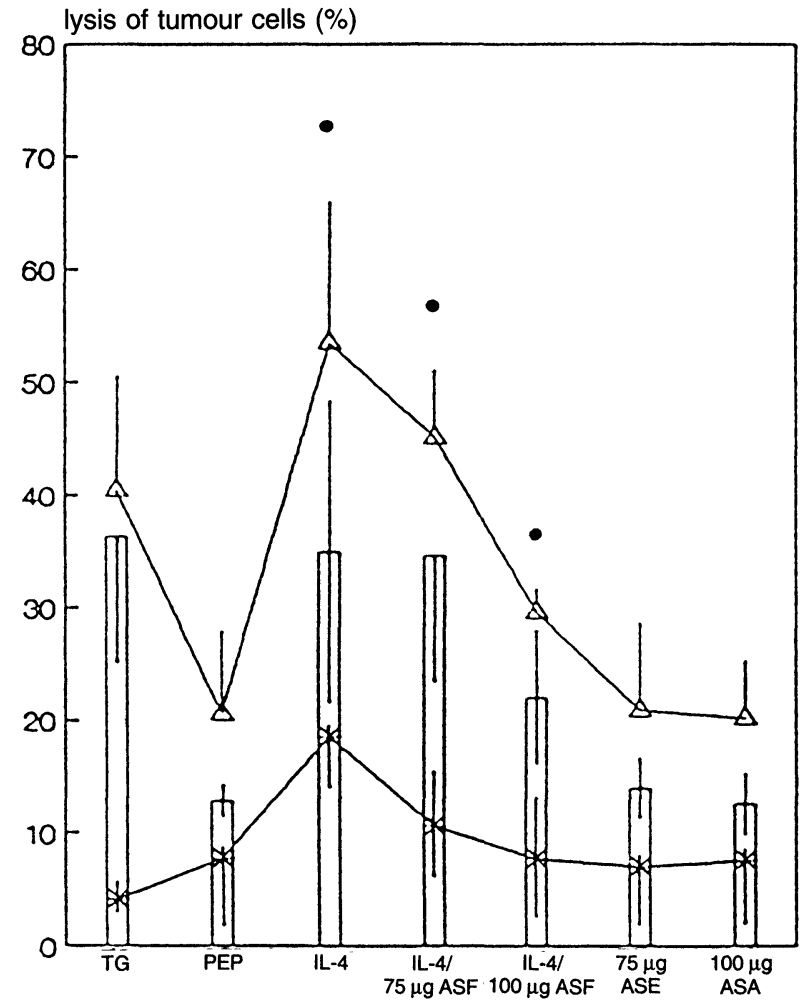

FIG. 2. Results of ASA costimulation with IL-4 in tumour cell lysis Peritoneal macrophages (MP) from mice injected with protease peptone (PEP) were prepared at $1 \times 10^{5} \mathrm{MP} /$ well. After nonadherent cells were removed, $200 \mu \mathrm{l} \mathrm{MEM+}$ with either 75 or $100 \mu \mathrm{g} \mathrm{ASA} / \mathrm{ml}$ with or without $20 \mathrm{U}$ $\mathrm{IL}-4 / \mathrm{ml}$ were added. After $24 \mathrm{~h}$ the total volume was replaced by $200 \mu$ fresh medium with $4 \times 10^{4}\left[{ }^{3} \mathrm{H}\right]$ thymidine-labelled SW 948 cells, and with or without antibodies (Ab). After $48 \mathrm{~h}, 100 \mu \mathrm{l}$ supernatant was aspired from each sample and cpm were determined. The cell lysis with $A b(\triangle)$, the cell lysis without $A b(*)$, and the ADCC (bars) were calculated as described in the text. Thioglycollate (TG) elicited MPs served as control, only. $(\bullet)$ Significantly different to PEP-control.

Whereas the binding capacity of the macrophages with respect to the tumour cells without antibodies was found to be uninfluenced in all reactions, the antibody-assisted binding capacity of the thioglycollate-elicited macrophages showed a significant increase. Macrophage stimulation with IL-4 and ASA or a combination of the two led to a slight, but not significant, increase in bonds (Figs 3 and 4).

Stimulation of the peptone-elicited macrophages with $100 \mathrm{U}$ IFN-gamma/ml significantly increased the ADCC value and tumour toxicity in the presence of antibodies in comparison with controls (Fig. 5). In contrast, no significant increase in macrophage activity was observed on costimulation with $75 \mu \mathrm{g}$ $\mathrm{ASA} / \mathrm{ml}$. As a result of the reduction in antibodydependent tumour toxicity, this value was found to be between that of the peptone controls and that after activation with IFN-gamma, without differing significantly from either of these (Fig. 5).

The binding capacity of the macrophages was affected neither positively nor negatively by IFNgamma and/or ASA (Fig. 6). 


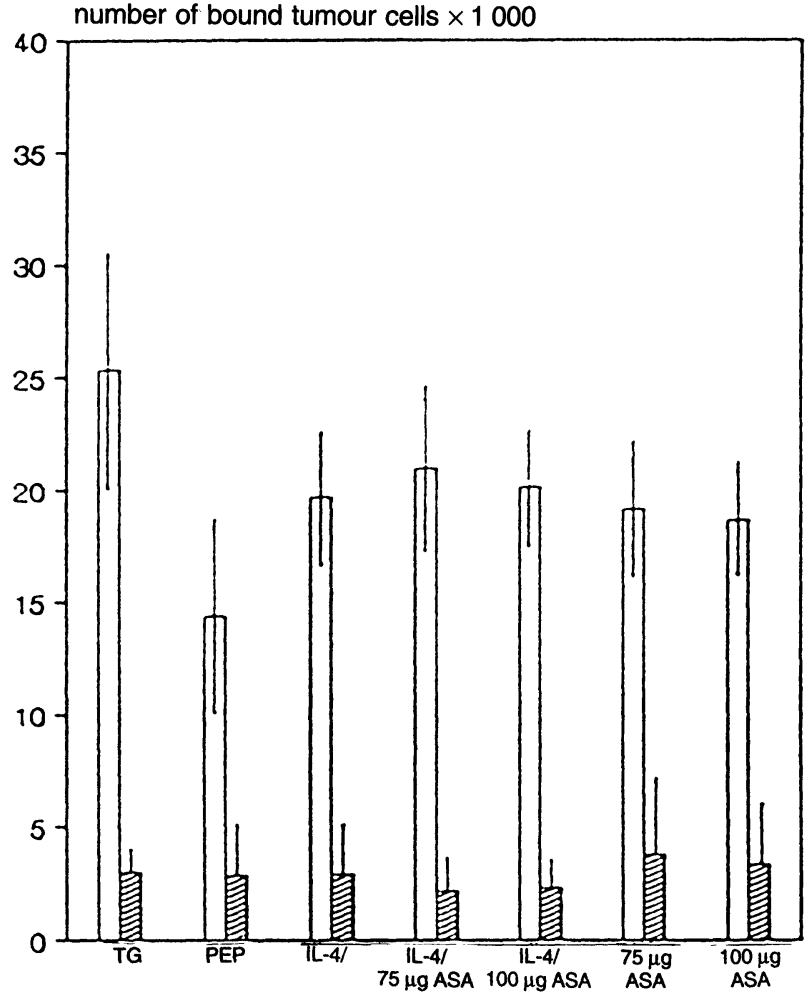

FIG. 3. Results of ASA costimulation with IL-4 on bound tumour cells. Peritoneal macrophages (MP) from mice injected with protease peptone (PEP) were prepared at $1 \times 10^{5} \mathrm{MP} /$ well. After nonadherent cells were removed, $200 \mu \mathrm{l} \mathrm{MEM}{ }^{+}$with 75 or $100 \mu \mathrm{g} \mathrm{ASA}$ with or without $10 \mathrm{U} \mathrm{IL-4/m}$ were added. After $24 \mathrm{~h}$ the total volume was replaced with $200 \mu \mathrm{l}$ fresh medium with $4 \times 10^{4}\left[{ }^{3} \mathrm{H}\right]$ thymidine-labelled SW 948 cells, and with or without antibodies (Ab). After $15 \mathrm{~min}$, the total volume was aspired from each sample and cpm were determined. The number of bound tumour cells with $\mathrm{Ab}$ (clean bars) or without $\mathrm{Ab}$ (striped bars) were calculated as described in the text. Thioglycollate (TG) elicited macrophages served as control only.

\section{Discussion}

A comparison of our results reveals a consistent tendency of ASA to have no essential effect on the activity of murine peritoneal macrophages in vitro. Macrophage activation, such as that induced by IL-4 and IFN-gamma, was not observed, and there was also no synergism between ASA and the cytokines. No increase or inhibition of macrophage activity was observed, although slight inhibition occurred in the experiments with costimulation with IFN-gamma. The immunostimulant effect of ASA reported in the literature could not be confirmed on the basis of the ADCC model. The inhibition of prostaglandin synthesis by the therapeutically effective concentrations of ASA used might play a role as a possible explanation for this in vivo, since prostaglandins, and especially PGE, are among the inhibitory immunomediators within the immune regulation system and are responsible for a number of immunosuppressive mechanisms at the level of cellular immunity. ${ }^{15,37-39}$ It is therefore likely that prostaglandin synthesis inhibitors can act as immunostimulants. Thus, cyclooxygenase inhibition number of bound tumour cells $\times 1000$

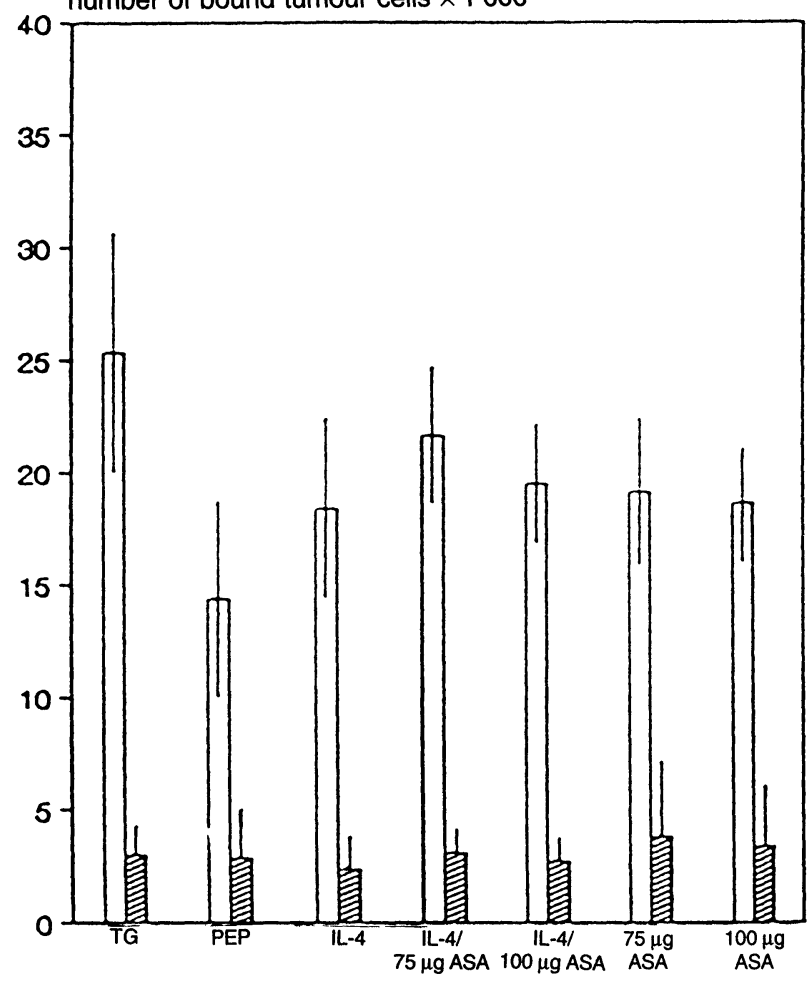

FIG. 4. Results of ASA costimulation with IL-4 on bound tumour cells. Peritoneal macrophages (MP) from mice injected with protease peptone (PEP) were prepared at $1 \times 10^{5} \mathrm{MP} /$ well. After nonadherent cells were removed, $200 \mu \mathrm{l} \mathrm{MEM}{ }^{+}$with 75 or $100 \mu \mathrm{g} \mathrm{ASA}$ with or without $20 \mathrm{U} \mathrm{IL-4/m}$ were added. After $24 \mathrm{~h}$ the total volume was replaced with $200 \mu \mathrm{l}$ fresh medium with $4 \times 10^{4}\left[{ }^{3} \mathrm{H}\right]$ thymidine-labelled SW 948 cells, and with or without antibodies (Ab). After $15 \mathrm{~min}$, the total volume was aspired from each sample and cpm were determined. The number of bound tumour cells with $\mathrm{Ab}$ (striped bars) or without $\mathrm{Ab}$ (striped bars) were calculated as described in the text. Thioglycollate (TG) elicited macrophages served as control only.

leads to increased macrophage activity, manifested by an increased production of IL- $1 .^{40}$ In turn, IL- 1 leads to a stimulation of T- and B-lymphocytes. ${ }^{41}$ The elevated synthesis rates of IL-2 and IFN-gamma after administration of ASA can therefore be explained by an interaction of macrophages and lymphocytes with their mutual activation. ${ }^{3-5}$

The need for the presence of macrophages is indicative of primary stimulation of the macrophages by ASA. No such immunostimulant action of ASA on isolated peritoneal macrophages was detected in this study. The therapeutic concentrations of ASA achievable in human blood $(75-100 \mu \mathrm{g} / \mathrm{ml})$ have no direct influence on macrophages under in vitro conditions. This applies both to the binding capacity and to the antibody-dependent and -independent tumour toxicity of mouse peritoneal macrophages. The ADCC of macrophages is likewise not changed in either direction by ASA, even though prostaglandins suppress ADCC and the tumour-toxic activity of macrophages. ${ }^{12-15}$ In the selected experimental design this effect evidently does not come into operation. Our findings are therefore in agreement with the results obtained by Hockertz et al., ${ }^{42}$ who were 


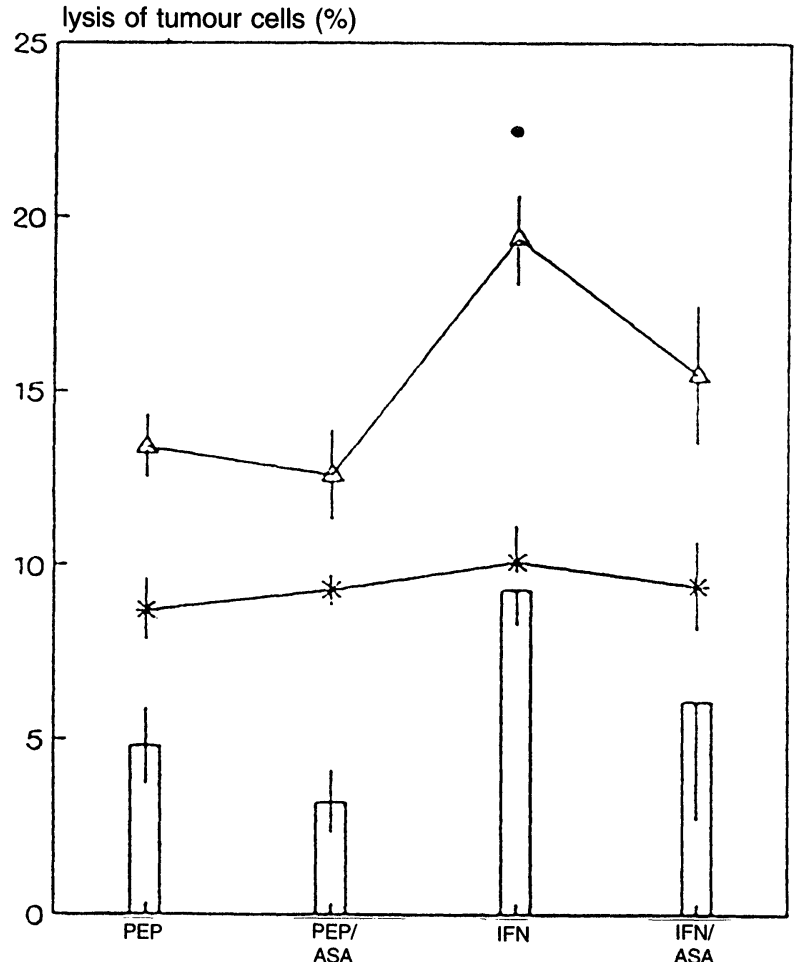

FIG. 5. Effect of ASA costimulation with IFN-gamma on tumour cell lysis. Peritoneal macrophages (MP) from mice injected with protease peptone (PEP) were prepared at $1 \times 10^{5} \mathrm{MP} /$ well. Two $h$ before starting the ADCC medium was aspired and replaced with fresh $\mathrm{MEM}^{+}$containing either $75 \mu \mathrm{g}$ $\mathrm{ASA} / \mathrm{ml}$ or $100 \mathrm{U}$ IFN-gamma/ml or both, respectively. After the appropriate period of time, medium was aspired and $200 \mu$ l medium with $4 \times 10^{4}$ $\left[{ }^{3} \mathrm{H}\right]$ thymidine-labelled SW 948 cells with or without antibodies $(\mathrm{Ab})$ were added to each well. After $48 \mathrm{~h}, 100 \mu \mathrm{l}$ were aspired from each sample and $\mathrm{cpm}$ were determined. The cell lysis with $A b(\triangle)$, the cell lysis without $A b$ (*), and the ADCC (bars) were calculated as described in the text. IFNgamma significantly increases the ADCC in correspondence to cell lysis with $\mathrm{Ab}$. ASA reduces the effect of IFN-gamma. (๑) Significantly different to PEP-control.

likewise unable to observe any effect of ASA on isolated murine peritoneal macrophages. In addition to the unchanged production of IL- 6 , the production of oxygen radicals also remained unchanged, although these play an important part as tumour-toxic effector substances of the macrophages precisely in the ADCC reaction. ${ }^{43-45}$

The stimulation of the macrophages by the cytokines IFN-gamma and IL-4 corresponds to the findings of other studies. ${ }^{31,46-48}$ A slight change in macrophage activity was observed only on costimulation with IFN-gamma and ASA. In this case the antibody-dependent cytotoxicity and the ADCC values were inhibited by costimulation with ASA. It may be that costimulation causes an increase in the cAMP level, which exerts an inhibitory effect on the macrophages and their ADCC activity. ${ }^{49,50}$ By contrast ASA exhibits neutral behaviour in tumour patients receiving IFN. ${ }^{51}$ There is no synergistic effect between stimulant cytokines and ASA.

Looking at the results overall, the antibodydependent and -independent tumour toxicity and the binding capacity of peritoneal macrophages are

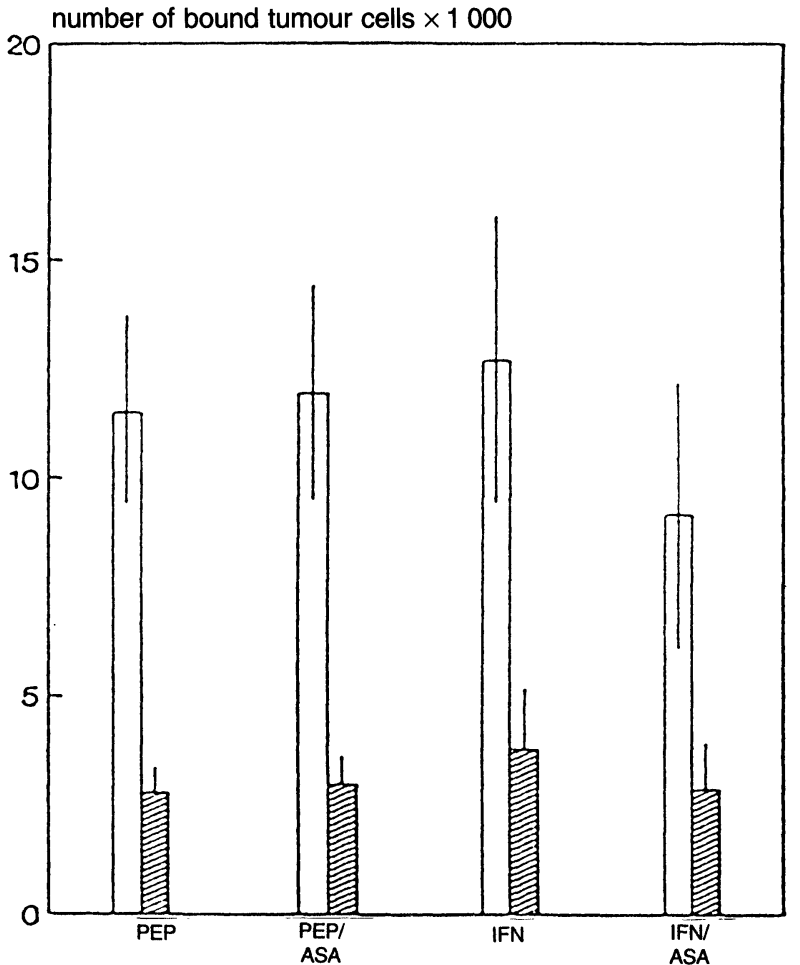

FIG. 6. Effect of ASA costimulation with IFN-gamma on tumour cell binding Peritoneal macrophages (MP) from mice injected with protease peptone (PEP) were prepared at $1 \times 10^{5} \mathrm{MP} /$ well. Two $h$ before starting the binding assay medium was aspired and replaced with fresh $\mathrm{MEM}^{+}$containing eithe $75 \mu \mathrm{g} \mathrm{ASA} / \mathrm{ml}$ or $100 \mathrm{U}$ IFN-gamma/ml or both, respectively. After the appropriate period of time, medium was aspired and $200 \mu \mathrm{l}$ medium with 4 $\times 10^{4}\left[{ }^{3} \mathrm{H}\right]$ thymidine-labelled SW 948 cells with or without Ab were added to each well. After $15 \mathrm{~min}$, the total volume was aspired from each sample and $\mathrm{cpm}$ were determined. The number of bound tumour cells with $\mathrm{Ab}$ (clean bars) or without $A b$ (striped bars) were calculated as described in the text.

not directly influenced in vitro by the presence of ASA. The positive immunological influence of ASA is therefore very probably closely connected with an interaction between defence cells and their cytokines. It is still unclear to what extent ASA can be used as a direct immunostimulant or immunomodulator, but its clinical use, e.g. as an adjuvant in inoculations, could be of major importance.

\section{References}

1. Zatz MM, Skotnicki A, Bailey JM, Oliver JH, Goldstein AL. Mechanism of action of thymosin. II. Effects of aspirin and thymosin on enhancement of IL-2 production Immunopharmacology 1985; 9: 189-198.

2. Yousefi S, Chiu J, Carandang G, Archibeque EG, Vaziri N, Cesario TC. Effect of acetylsalicylic acid on reduction and action of leukocyte-derived interferons. Antimicrob Agents Chemother 1987; 31: 114-116.

3. Cesario TC, Yousefi S, Carandang G. The regulation of interferon production by aspirin, other inhibitors of the cyclooxygenase pathway and agents influencing calcium channel flux. Bull NY Acad Med 1989; 65: 26-35.

4. Hsia J, Sarin N, Oliver JH, Goldstein AL. Aspirin and thymosin increase interleukin2 and interferon-gamma production by human peripheral blood lymphocytes. Immunopharmacology 1989; 17: 167-173.

5. Hsia J, Simon GL, Higgins N, Goldstein AL, Hayden FG. Immune modulation by aspirin during experimental rhinovirus colds. Bull NY Acad Med 1989; 65: 45-56.

6. Pugliese A, Maggiolo F. Torre D, Forno B, Pollono AM, Martelli ML, Biglino A. Influence of acetylsalicylic acid and of salicylic acid on mediators of immune response. Int J Immunotherapy 1991; 7: 31-35. 
7. Hsia J, Tang T. Aspirin a biological response modifier. In: Goldstein AL, Garaci E, eds. Combination Therapies. New York: Plenum Press, 1992; 131-137.

8. Juan H. Kürzlich entdeckte Wirkungsmechanismen der nichtsteroidalen Antirheumatika: Mögliche, nicht nur symptomatische therapeutische Effekte. Wiener Klin Wocbenschr 1983; 95: 865-869.

9. Rumore MM, Aron SM, Hiross EJ. A review of mechanism of action of aspirin and its potential as an immunomodulating agent. Med Hypotheses 1987; 22: 387-400.

10. Roth GJ, Siok CJ. Acetylation of the $\mathrm{NH}_{2}$-terminal serine of prostaglandin synthetase by aspirin. J Biol Chem 1978; 253: 3782-3784

11. Waymack JP. Effect of prostaglandin $\mathrm{E}$ on immune function in multiple anima models. Arch Surg 1988; 123: 1429-1432.

12. Droller MJ, Schneider MU, Perlmann P. A possible role of prostaglandins in the inhibition of natural and antibody-dependent cell-mediated cytotoxicity agains tumor cells. Cell Immunol 1978; 39: 165-177.

13. Trofatter KF, Daniels A. Interaction of human cells with prostaglandins and cyclic AMP modulators. J Immunol 1979; 122: 1363-1370.

14. Taffet SM, Russell SW. Macrophage-mediated tumor cell killing: regulation of expression of cytolytic activity by prostaglandin E. J Immunol 1980; 126: 424-427.

15. Goodwin JS, Ceuppens J. Regulation of the immune response by prostaglandins. J Clin Immunol 1983; 3: 295-315.

16. Schenkelaars EJ, Bonta IL. Cyclooxygenase inhibitors promote the leukotriene $\mathrm{C}$ induced release of beta-glucuronidase from rat peritoneal macrophages: prostaglandin $\mathrm{E}_{2}$ suppresses. Int J Immunopharmac 1986: 8: 305-311.

17. Voth R, Chmielarczyk W, Storch E, Kirchner H. Induction of natural killer cell activity in mice by injection of indomethacin. Nat Immun Cell Growth Regul 1986, 5: $317-324$.

18. Field WE, Ferguson FG, Reddanna P, Reddy CC. The effect of selected arachidonic acid metabolites on natural killer cell activity. Prostaglandins 1988; 36: 411-419.

19. Plescia OJ, Smith AH, Ginwich K. Subversion of immune system by tumor cells role of prostaglandins. Proc Natl Acad Sci USA 1975; 72: 1848-1851.

20. Lupulescu A. Enhancement of carcinogenesis by prostaglandins. Nature $1978 ; \mathbf{2 7 2}$ 634-636

21. Young MR, Newby M. Differential induction of suppressor macrophages by cloned Lewis lung carcinoma variants in mice. JNCI 1986; 77: 1255-1260.

22. Young MR, Wheeler $E$, Newby $M$. Macrophage-mediated suppression of natural killer cell activity in mice bearing Lewis lung carcinoma. JNCI 1986; 76: 745-750.

23. Young MR, Newby M. Enhancement of Lewis lung carcinoma cell migration by prostaglandin $\mathrm{E}_{2}$ produced by macrophages. Cancer Res 1986; 46: 160-164.

24. Hial V, Horakova Z, Shaff R, Beaven MA. Alteration of tumor growth by aspirin and indomethacin: studies with two transplantable tumors in mouse. Eur J Pharmacol 1976; 37: 367-376

25. Lynch NR, Castes M, Astoin M, Salomon JC. Mechanism of inhibition of tumo growth by aspirin and indomethacin. BrJ Cancer 1978; 38: 503-512.

26. Valdez JC, Perdigon G. Piroxicam, indomethacin and aspirin action on a murine fibrosarcoma. Effects on tumor-associated and peritoneal macrophages. Clin Exp Immunol 1991; 86: 315-321.

27. Brunda MJ, Herberman RB, Holden HT. Inhibition of murine natural killer cell activity by prostaglandins. J Immunol 1980; 124: 2682-2687.

28. Thun MJ, Namboodiri MM, Heath CW. Aspirin use and reduced risk of colon cancer. New Engl J Med 1991; 325: 1593-1596.

29. Adams DO, Hall T, Steplewski Z, Koprowski H. Tumors undergoing rejection by monoclonal antibodies of $\mathrm{IgG} 2 \mathrm{a}$ isotype contain increased numbers of macrophages activated for a distinctive form of antibody-dependent cytolysis. Proc Natl Acad SCi USA 1984; 81: 3506-3510.

30. Weiner LM, Steplewski Z, Koprowski H, Sears HF, Litwin S, Comis RL. Biologica effects of gamma interferon pre-treatment followed by monoclonal antibody $17-1 \mathrm{~A}$ administration in patients with gasatrointestinal carcinoma. Hybridoma 1986; 5 S65-S77.

31. Fan S, Fehr HG, Adams DO. Activation of macrophages for ADCC in vitro: effects of IL-4, TNF, interferons alpha/beta, interferon-gamma, and GM-CSF. Cell Immunol 1991; 135: 78-87.

32. Leibovitz A, Stinson WB, McCombs WB, McCoy CE, Mazur KC, Maybry ND Classification of human colorectal adenocarcinoma cell lines. Cancer Res 1976; 36 4562-4569.
33. Johnson WJ, Bolognesi DP, Adams DO. Antibody-dependent cytolysis (ADCC) of tumor cells by activated murine macrophages is a two-step process: quantification of target binding and subsequent target lysis. Cell Immunol 1984; 83: 170-180.

34. Adams DO. Quantitation of adherent mononuclear phagocytes by inverted phase microscopy. In: Adams DO, Edelson PE, Koren H, eds. Methods for Studying Mononuclear Phagocytes. New York: Academic Press, 1981; 325-330.

35. Adams DO, Hamilton TA. Phagocytic cells. Cytotoxic activities of macrophages. In Gallin JJ, Goldstein JM, Snyderman R, eds. Inflammation: Basic Principles and Clinical Correlates. New York: Raven Press, 1988; 471-491.

36. Johnson WJ, Adams DO. Assays detecting the antibody-dependent and independen binding and cytolysis of tumor cells by murine macrophages. In: Colowick S, Plam NO, eds. Methods in Enzymology, Vol 132. New York: Academic Press, 1986, $555-568$.

37. Goodwin JS, Webb DR. Regulation of immunoresponse by prostaglandins. Clin Immunol Immunopath 1980; 15: 106-122.

38. Rappaport RS, Dodge GR. Prostaglandin E inhibits the production of human interleukin 2. J Exp Med 1982; 155: 943-948.

39. Chouaib S, Chatenould L, Klatzmann D, Fradelizi D. The mechanisms of inhibition of human IL 2 production. II. $\mathrm{PGE}_{2}$ induction of suppressor $\mathrm{T}$ lymphocytes J Immunol 1984; 133: 1851-1857.

40. Kunkel SL, Chensue SW, Phan SH. Prostaglandins as endogenous mediators of interleukin 1 production. J Immunol 1986; 136: 186-192.

41. Dinarello CA. Interleukin-1 and the effects of cyclooxygenase inhibitors on it biological activities. Bull NY Acad Med 1989; 65: 80-92.

42. Hockertz S, Schettler T, Rogalla K. Effect of acetylsalicylic acid, ascorbate and ibuprofen on the macrophage system. Arzneim Forsch Drug Res 1992; 42 1062-1068.

43. Nathan CF. Reactive oxygen intermediates in lysis of antibody-coated tumor cells. In: Koren HS, ed. Macrophage-mediated Antibody-dependent Cellular Cytotoxicity. New York: Dekker, 1983; 199-216.

44. Adams DO, Hamilton TA. Destruction of tumor cells by mononuclear phagocytes models of analysing effector mechanisms and regulation of macrophage activation. In: North RJ, Steinman RM, eds. Basic Mechanisms of Host Resistance to Infectious Agents, Tumors and Allografts. New York: Rockefeller University Press, 1986 185-204.

45. Adams DO. Molecular interactions in macrophage activation. Immunol Today 1989; 10: $33-35$.

46. Somers SD, Erickson KL. Regulation of murine macrophage function by IL-4. I Activation of macrophages by a T-T cell hybridoma is due to IL-4. Cell Immunol 1989; 22: 178-187.

47. Nacy A, Meltzer MS. T-cell-mediated activation of macrophages. Current Opinion Immunol 1991; 3: 330

48. Wersäll P, Masucci G, Mellstedt H. Interleukin-4 augments the cytotoxic capacity of lymphocytes and monocytes in antibody-dependent cellular cytotoxicity. Cancer Immunol Immunother 1991; 33: 45-49.

49. Garovoy MR, Strom TB, Kaliner M, Carpenter CB. Antibody-dependent lymphocyte mediated cytotoxicity mechanism and modulation by cyclic nucleotides. Cell Immunol 1975; 20: 197-204.

50. Okonogi K, Gettys TW, Uhing RJ, Tarry WC, Adams DO, Prpic V. Inhibition of prostaglandin E2-stimulated cAMP accumulation by lipopolysaccharide in murine peritoneal macrophages. J Biol Chem 1991; 266: 10305-10312.

51. Creagan ET, Twito DI, Johansson SL, Schaid DJ, Johnson PS, Flaum MA, Buroke TR, Geeraerts $\mathrm{LH}$, Veeder $\mathrm{MH}$, Gesme $\mathrm{DH}$, Homburger $\mathrm{HA}$. A randomized prospective assessment of recombinant leukocyte A human interferon with or without aspirin in advanced renal adenocarcinoma. J Clin Oncol 1991; 9: 2104-2109.

ACKNOWLEDGEMENTS. We thank Mrs M. Euler and Mrs M. Maskus for their excellen technical assistance, and Mrs S. Becker for her patient secretarial services.

Received 1 March 1994;

accepted in revised form 15 July 1994 


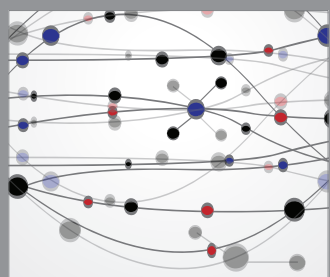

The Scientific World Journal
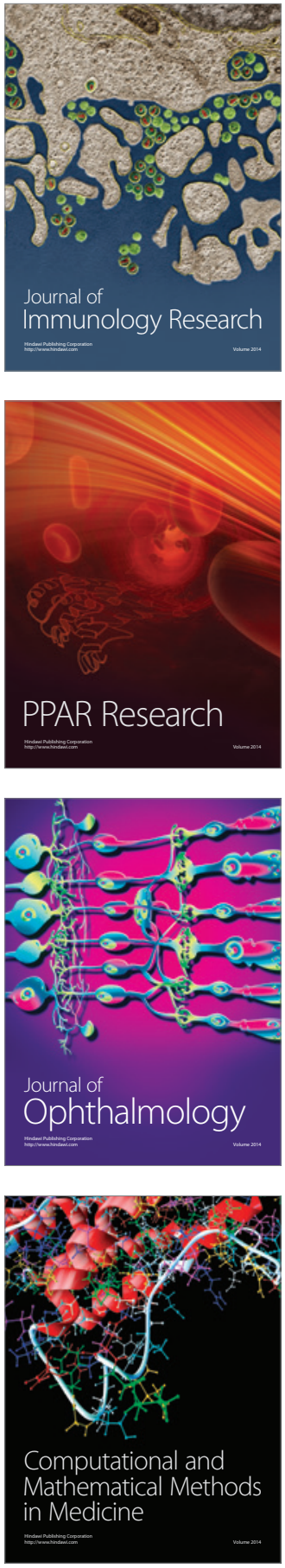

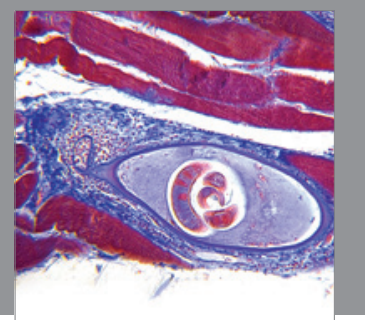

Gastroenterology

Research and Practice
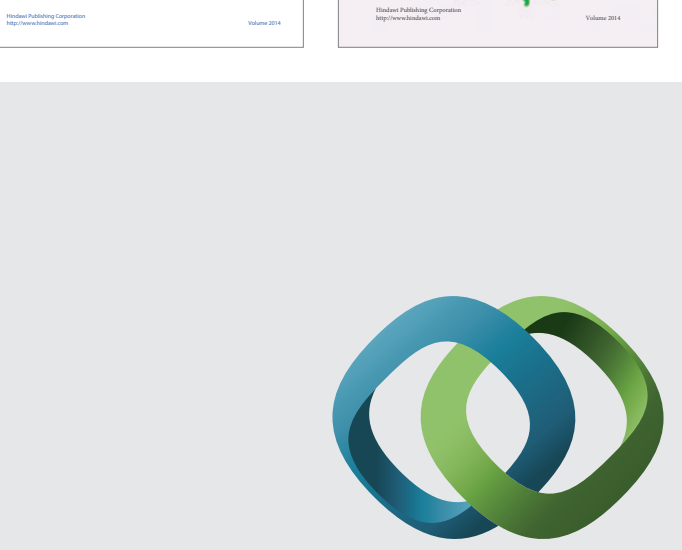

\section{Hindawi}

Submit your manuscripts at

http://www.hindawi.com
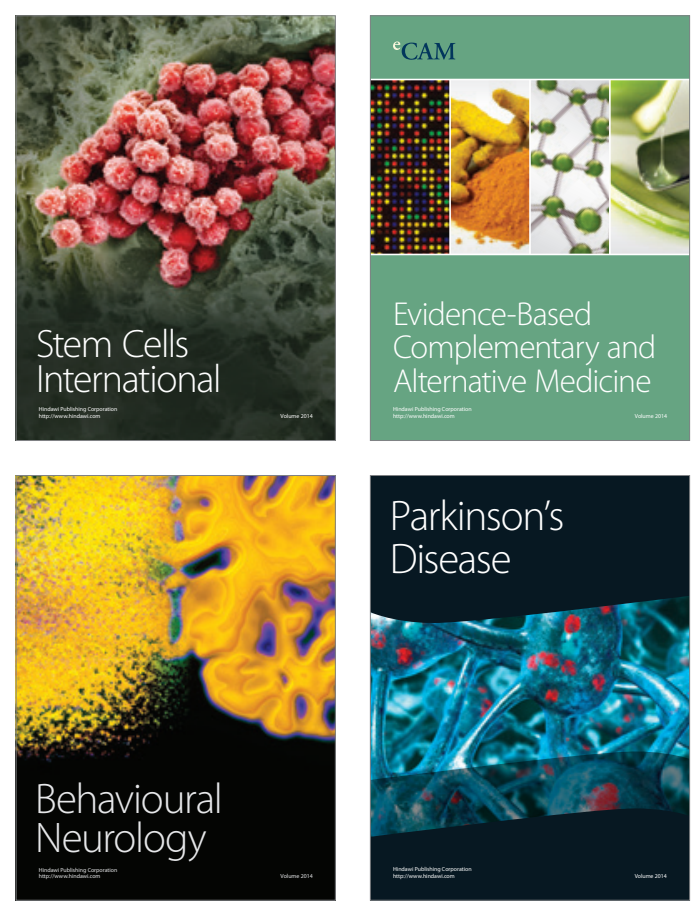

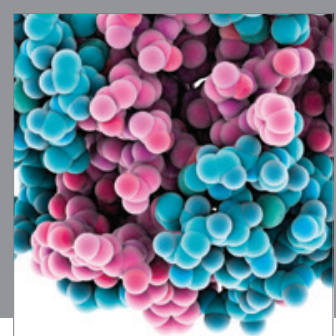

Journal of
Diabetes Research

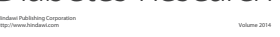

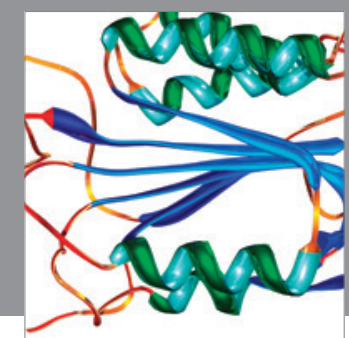

Disease Markers
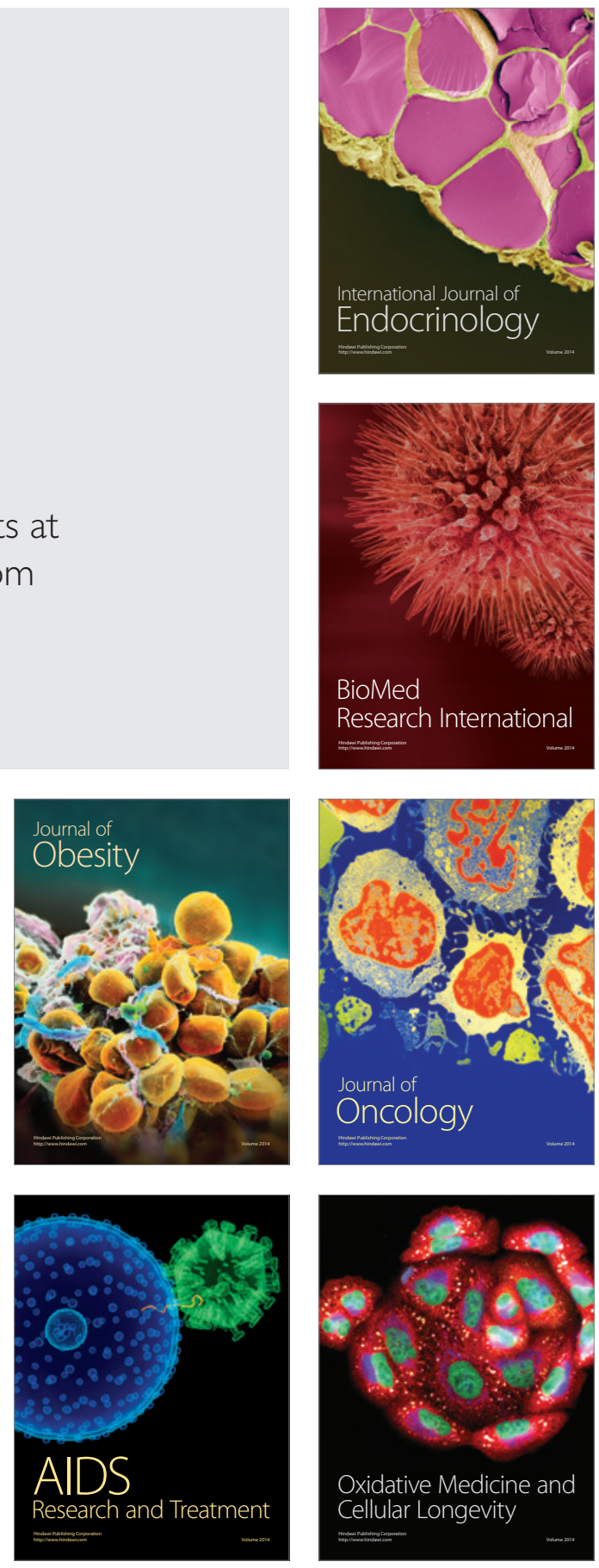